\title{
Impact of diets with different oil sources on growth performance, whole body composition, physiological parameters for Nile tilapia, Oreochromis niloticus fingerlings
}

\author{
Mohammad H. Ahmad ${ }^{1}$, Asmaa S. Abd El-Naby ${ }^{1}$ and Amani El- \\ Mesallamy $^{2}$ \\ ${ }^{1}$ Fish Nutrition Department, Central Lab for Aquaculture Research, Abassa, \\ Abu Hammad, Sharkia, Egypt. \\ ${ }^{2}$ Chemistry Department, Faculty of Science, Zagazig University, Zagazig, \\ Egypt
}

\begin{abstract}
The aim of this work was to investigate the effect of the dietary supplementation of different oil sources on the performance and physiological parameters of Nile tilapia. Seven isonitrogenous (30\% crude protein) and isocaloric $(4.40 \mathrm{kcal} / \mathrm{g})$ experimental diets were formulated to containing different oils sources at the same levels (5\%) including T1: cod liver oil; T2: poultry by product oil; T3: linseed oil; T4: corn oil; T5: $50 \%$ linseed oil $+50 \%$ poultry by product oil; T6: $50 \%$ corn oil $+50 \%$ poultry by product oil and control without oils. Fish $(6.41 \pm 0.01 \mathrm{~g})$ were selected and randomly distributed at a rate of 15 fish/100-L aquarium in triplicates. The feeding rate was $3 \%$ of live body weight for 12 weeks. The chemical profiles of fatty acids were analyzed by Gas chromatographic analysis (GCFID). Results showed that the optimum growth-related parameters were obtained at T5. Fish fed T3 diet gave higher feed intake than other different oil sources while fish fed T5 diet showed the best (lowest) for feed conversion ratio (FCR) in comparison to the control diet and other treatments. In regard to body composition, there were no significant differences with fish protein and lipid contents $(\mathrm{P}>0.05)$ in all diets supplemented with different oil sources. Diets supplemented with different dietary oil sources showed the best physiological parameters in comparison with the control diet .The blood hemoglobin ( $\mathrm{Hb})$, red blood cells (RBCs) and hematocrit (Ht) were higher in Nile tilapia fed T5. Total serum protein and glucose in plasma were increased
\end{abstract}


significantly in the group of fish consumed T5. T5 diet is more economic and reduced the oil cost in fish feed without any effect on growth performance or feed utilization. The reduction in feed cost compared with the control diet to produce one $\mathrm{kg}$ fish gain was highest in $\mathrm{T} 2$ diet followed by T5 diet.

Keywords: Cod liver oil, poultry by product oil, linseed oil, corn oil, Nile tilapia, fatty acids, growth performance, feed utilization, whole-body composition, physiological parameters and economic evaluation.

\section{Introduction}

The oils in fish diets are a significant source of energy, and they also play significant roles in a range of important physiological functions. This refers in particular to the so-called essential fatty acids (EFA). These have an impact on, among other processes, embryogenesis, ovulation, immunity, stress reactions, and adaptation mechanisms in fish (Sargent et al. 2002; Bell and Sargent 2003).

Changes in aqua-feed have been characterized by an increase in dietary lipid levels to reduce nitrogen wastes and improve growth performance. This evolution combined with the strong increase in aquaculture production has led to a rise in demand for fish oils, while their availability remains limited. Key alternatives include vegetable oils reducing the part of marine resources in aqua-feed high-quality marine fish oils have been used almost exclusively as dietary lipid sources in the formulation of commercial fish feeds. However, vegetable oils used as alternative to fish oil consisted lately of an important part of the research on fish nutrition. Nevertheless, lipid digestibility was higher in diets containing vegetable oil than with animal lipid in Atlantic salmon fed diets based on flaxseed oil (Menoyo et al., 2007) and in Atlantic halibut fed diets based on vegetable oil (Martins et al., 2009).

Unlike fish oil, vegetable oils are less expensive and do not accumulate persistent organic pollutants (POPs), thus production costs can be lowered with vegetable oil-based diets, as well as contaminant exposure for fish and consumers. Some vegetable oils are considered as good alternative lipid sources in salmonids and freshwater fish feeds without affecting growth performance and feed conversion (Bell $\boldsymbol{e t}$ al., 2001 and Caballero et al., 2002). In addition to traditional performance indicators of feed additives such as growth and, survival and physiological status could be evaluated. Therefore, the present study was 
conducted to investigate the effect of different oils supplementation on growth performance, feed utilization, survival, whole-body composition and physiological parameters of Nile tilapia. Also, the economic evaluation was done.

\section{Material and methods}

1- Gas chromatographic analysis of fatty acid methyl esters (GCFID):

\section{1-Preparation of fatty acid methyl ester:}

Fatty acid methyl ester (FAME) was prepared according to the AOAC method as the following Tsimidou and Boskou, (1995):

$0.5 \mathrm{~g}$ of the oil sample weighed accurately into the flask $(30 \mathrm{ml})$ and5 $\mathrm{ml}$ of $0.5 \mathrm{M}$ methanolic sodium hydroxide solution was added for the saponification. Reflux condenser $(15 \mathrm{~cm}$, in length) was attached to the flask and heated at $140^{\circ} \mathrm{C}$ for $5 \mathrm{~min}$. then on the heating mantle. $5 \mathrm{ml}$ of boron trifluoride-methanol was added from pipet through condenser and continued heating at $140^{\circ} \mathrm{C}$ for $5 \mathrm{~min}$. The flask was removed from heating mantle and reflux, the solution allowed to stand at room temperature. $5 \mathrm{ml}$ of $\mathrm{n}$-hexane and about $10 \mathrm{ml}$ of saturated sodium chloride solution were added, and then the content was agitated thoroughly. An aliquot of the supernatant hexane layer was transferred into a Pasteur pipet (5 3/4 inch) in which packed anhydrous sodium sulfate (about $1 \mathrm{~g}$ ) to remove water. Following filtration, $0.1 \mathrm{ml}$ of filtrate was analyzed by GC or GC \pm MS.

Fatty acids were identified by comparison of their retention times with those of pure reference standards.

\section{2- Determination of fatty acid by Gas chromatography:}

Gas chromatography for analysis of fatty acid methyl ester using a Hewlett-Packard 6890 chromatograph equipped with a flame-ionization detector (FID). A capillary column (HP Innowax): $30 \mathrm{~m} 0.25 \mathrm{~mm} 0.25 \mu$ $\mathrm{m}$ with a stationary phase of polyethylene glycol and oven temperature program: isotherm at $150^{\circ} \mathrm{C}$ during $1 \mathrm{~min}$, from $150{ }^{\circ} \mathrm{C}$ to $200{ }^{\circ} \mathrm{C}$ at the rate of $15^{\circ} \mathrm{C} / \mathrm{min}$, from $200^{\circ} \mathrm{C}$ to $242^{\circ} \mathrm{C}$ at the rate of $28 \mathrm{C} / \mathrm{min}$ and isotherm at $225^{\circ} \mathrm{C}$ during $2 \mathrm{~min}$. Injector and detector temperatures were respectively held at 250 and $275^{\circ} \mathrm{C}$. Carrier gas was nitrogen at a flow rate of $1.6 \mathrm{ml} / \mathrm{min}$. 


\section{2- Experimental design and dietary treatments:}

Seven experimental diets (30\% crude protein and $7 \%$ lipid) were formulated containing to containing different oils sources at the same levels (5\%) including T1: cod liver oil; T2: poultry by product oil; T3: linseed oil; T4: corn oil; T5: $50 \%$ linseed oil $+50 \%$ poultry by product oil; T6: $50 \%$ corn oil $+50 \%$ poultry by product oil and control without oils. The proximate chemical compositions of main ingredients of the tested diets are shown in Table 1 . The dry ingredients of each diet were thoroughly mixed, and $100 \mathrm{ml}$ of water was added per $\mathrm{kg}$ diet. Afterwards, the mixture (ingredients and water) was blended using a kitchen blender to make a paste of each diet. Pelleting of each diet was carried out by passing the blended mixture through a laboratory pellet machine with a 1-mm-diameter die. The pellets were dried in a drying oven for 24 hours at $85^{\circ} \mathrm{C}$ and stored in plastic bags in a deep freezer at $-2^{\circ} \mathrm{C}$ until use. The caloric value as growth energy (DG) of each ingredient was estimated on the basis of $5.65 \mathrm{kcal} \mathrm{DE} / \mathrm{g}$ protein, 9.45 $\mathrm{kcal} \mathrm{DE} / \mathrm{g}$ lipid, and $4.11 \mathrm{kcal} \mathrm{DE} / \mathrm{g}$ of carbohydrate (NRC, 1993).

\section{3- Experimental fish and culture condition:}

All-male Nile tilapia, O. niloticus, fingerlings (treated with $17 \alpha$ methyl testosterone hormone) were obtained from the nursery ponds, Central Laboratory for Aquaculture Research (CLAR), Abbassa, AbuHammad, Sharkia, Egypt. Fish were held in a fiberglass tank for two weeks for acclimation during which they were fed a formulated diet containing $30 \%$ crude protein. Fifty fish were frozen at $-20{ }^{\circ} \mathrm{C}$ for initial proximate whole body analysis. After that, fish $(6.41 \pm 0.01 \mathrm{~g})$ were distributed randomly at a rate of 15 fish/100-L aquarium. Each aquarium was aerated by using small air-bumps. Settled fish wastes along with a half of the aquarium water was siphoned daily, and replaced by well-aerated and dechloronated tap water from a storage tank. Fish in all treatments were fed the tested diets at a rate of $3 \%$ of live body weight of the experimental. Diets were offered twice daily at 9:00 and 13:00 h for 12 weeks. Fish in each aquarium were sampled biweekly and the amount of feed adjusted accordingly. Dead fish were daily recorded and removed. At the end of the study, fish were individually weighed.

\section{4-Growth performance and feed utilization:}

Fish growth parameters and feed utilization were calculated as follows: 
Weight gain $(\mathrm{g})=\mathrm{W}_{2}-\mathrm{W}_{1}$;

Specific growth rate $(\mathrm{SGR} ; \% \mathrm{~g} /$ day $)=100\left(\mathrm{Ln} \mathrm{W} 2-\mathrm{Ln} \mathrm{W}_{1}\right) / \mathrm{T}$,

Where $\mathrm{W}_{1}$ and $\mathrm{W}_{2}$ are the initial and final weights, respectively, and $\mathrm{T}$ is the experimental period (days);

Feed conversion ratio $(\mathrm{FCR})=$ feed intake / weight gain;

Protein efficiency ratio $(\mathrm{PER})=$ weight gain / protein intake;

Apparent protein utilization ( APU; \% ) $=100$ [protein gain in fish

$(\mathrm{g}) /$ protein intake in diet $(\mathrm{g})]$;

Energy utilization $(\mathrm{EU} ; \%)=100$ [Energy gain in fish $(\mathrm{g}) /$ energy intake in diet $(\mathrm{g})]$.

\section{5- Proximate chemical analysis:}

Diets and fish were analyzed according to standard methods (AOAC, 1990) for moisture, crude protein, total lipids, and ash. Moisture content was estimated by drying samples in an oven at $85^{\circ} \mathrm{C}$ until constant weight was achieved. Nitrogen content was measured using a microKjeldahl apparatus, and crude protein was estimated by multiplying total nitrogen content by 6.25 . Total lipid content was determined by ether extraction for $16 \mathrm{~h}$, and ash was determined by combusting samples in a muffle furnace at $550^{\circ} \mathrm{C}$ for $6 \mathrm{~h}$. Crude fiber was estimated according to Goering and Van Soest, (1970). Gross energy was calculated according to (NRC, 1993).

\section{6-Physiological analysis:}

At the end of the feeding trial, three fish from each aquarium were taken for physiological investigation. Fish were anaesthetized using buffered tricaine methanesulfonate $(20 \mathrm{mg} / \mathrm{L})$, and blood was collected from the caudal vein with a sterile syringe and divided equally among three clean and dry tubes. The first part was centrifuged at 3,000 rpm for $15 \mathrm{~min}$ and the serum was stored at $-20^{\circ} \mathrm{C}$ for further assays. The second part was mixed with sodium fluoride as an anticoagulant and centrifuged at $3000 \mathrm{rpm}$ for $15 \mathrm{~min}$ for separation of plasma for glucose analysis. The last part was mixed with EDTA solution for measuring hemoglobin $(\mathrm{Hb})$, red blood cell (RBCS), and hematocrit (Ht). Hemoglobin level was determined colorimetrically using a spectrophotometer according to Stopkopf (1983). Hematocrit was determined using the microhaematocrit method 
(Schalm, 1975). Red blood cells were determined according to the method described by Natt and Herrick, (1952). Total lipid content was determined colorimetrically according to Joseph et al. (1972). Total protein content was determined colorimetrically according to Henry, (1964). Urea was determined according to Patton and Crouch, (1977). Creatinine was determined calorimetrically according to Henry, (1974).

Table (1): Ingredients and chemical analysis of the experimental diets (on dry matter basis) containing different oil sources

\begin{tabular}{|c|c|c|c|c|c|c|c|}
\hline \multirow[t]{2}{*}{ Ingredients } & Control & \multicolumn{6}{|c|}{ Treatment } \\
\hline & 0.0 & $\mathrm{~T} 1$ & $\mathrm{~T} 2$ & $\mathrm{~T} 3$ & $\mathrm{~T} 4$ & T5 & T6 \\
\hline Fish meal (HFM) & 9.1 & 9.1 & 9.1 & 9.1 & 9.1 & 9.1 & 9.1 \\
\hline Soybean meal (SBM) & 45.50 & 45.50 & 45.50 & 45.50 & 45.50 & 45.50 & 45.50 \\
\hline Ground corn (CNM) & 23.4 & 22.4 & 22.4 & 22.4 & 22.4 & 22.4 & 22.4 \\
\hline Wheat bran (WB) & 13 & 13 & 13 & 13 & 13 & 13 & 13 \\
\hline Vitamins premix & 6.0 & 2.0 & 2.0 & 2.0 & 2.0 & 2.0 & 2.0 \\
\hline Minerals Premix & 1.0 & 1.0 & 1.0 & 1.0 & 1.0 & 1.0 & 1.0 \\
\hline Starch & 2.0 & 2.0 & 2.0 & 2.0 & 2.0 & 2.0 & 2.0 \\
\hline Cod liver oil & 0.0 & 5.0 & 0.0 & 0.0 & 0.0 & 0.0 & 0.0 \\
\hline Poultry by-product oil & 0.0 & 0.0 & 5.0 & 0.0 & 0.0 & 2.5 & 2.5 \\
\hline Linseed oil & 0.0 & 0.0 & 0.0 & 5.0 & 0.0 & 2.5 & 0.0 \\
\hline Corn oil & 0.0 & 0.0 & 0.0 & 0.0 & 5.0 & 0.0 & 2.5 \\
\hline \multicolumn{8}{|c|}{ Chemical analysis (\%) } \\
\hline Dry matter & 91.01 & 91.16 & 91.52 & 91.65 & 91.35 & 91.45 & 90.98 \\
\hline Crude protein & 30.21 & 29.72 & 29.85 & 30.54 & 30.37 & 29.94 & 30.03 \\
\hline Crude fat & 3.48 & 8.16 & 8.21 & 8.47 & 8.35 & 8.37 & 8.45 \\
\hline Ash & 8.65 & 8.66 & 8.14 & 8.29 & 8.25 & 8.24 & 8.29 \\
\hline Fiber & 5.10 & 5.00 & 4.9 & 4.9 & 5.00 & 4.9 & 4.9 \\
\hline NFE & 52.56 & 48.46 & 48.9 & 47.80 & 48.03 & 48.55 & 48.33 \\
\hline GE(Kcal/100g) & 419.06 & 443.72 & 446.72 & 448.75 & 456.41 & 447.31 & 447.68 \\
\hline $\mathrm{P} / \mathrm{E}$ ratio & 72.08 & 66.98 & 66.82 & 68.05 & 66.54 & 66.93 & 67.08 \\
\hline
\end{tabular}

1-T1: cod liver oil; T2: poultry by product oil; T3: linseed oil; T4: corn oil; T5: $50 \%$ linseed oil $+50 \%$ poultry by product oil andT6:50\% corn oil $+50 \%$ poultry by product oil

2-Vitamin premix (per kg of premix): thiamine, $2.5 \mathrm{~g}$; riboflavin, $2.5 \mathrm{~g}$; pyridoxine, 2.0 g; inositol, $100.0 \mathrm{~g}$; biotin, $0.3 \mathrm{~g}$; pantothenic acid, $100.0 \mathrm{~g}$; folic acid, $0.75 \mathrm{~g}$; paraaminobenzoic acid, $2.5 \mathrm{~g}$; choline, $200.0 \mathrm{~g}$; nicotinic acid, $10.0 \mathrm{~g}$; cyanocobalamine, $0.005 \mathrm{~g}$; a-tocopherol acetate, $20.1 \mathrm{~g}$; menadione, $2.0 \mathrm{~g}$; retinol palmitate, 100,000 IU; cholecalciferol, 500,000 IU.

3- Mineral premix (g/kg of premix): $\mathrm{CaHPO}_{4} .2 \mathrm{H}_{2} \mathrm{O}, 727.2 ; \mathrm{MgCO}_{4} .7 \mathrm{H}_{2} \mathrm{O}, 127.5 ; \mathrm{KCl}$ 50.0; $\mathrm{NaCl}, \quad 60.0 ; \quad \mathrm{FeC}_{6} \mathrm{H}_{5} \mathrm{O}_{7} .3 \mathrm{H}_{2} \mathrm{O}, 25.0 ; \mathrm{ZnCO}_{3}, \quad 5.5 ; \mathrm{MnCl}_{2} .4 \mathrm{H}_{2} \mathrm{O}, 2.5$; $\mathrm{Cu}(\mathrm{OAc})_{2} . \mathrm{H}_{2} \mathrm{O}, 0.785 ; \mathrm{CoCl}_{3} .6 \mathrm{H}_{2} \mathrm{O}, 0.477 ; \mathrm{CaIO}_{3} .6 \mathrm{H}_{2} \mathrm{O}, 0.295 ; \mathrm{CrCl}_{3} .6 \mathrm{H}_{2} \mathrm{O}, 0.128$; $\mathrm{AlCl}_{3} .6 \mathrm{H}_{2} \mathrm{O}, 0.54 ; \mathrm{Na}_{2} \mathrm{SeO}_{3}, 0.03$.

4 -Nitrogen-Free Extract (calculated by difference $)=100-($ protein + lipid + ash + fiber $)$.

5- Gross energy (GE) was calculated from NRC, (1993) as 5.65, 9.45, and4.1 kcal/g for protein, lipid, and carbohydrates, respectively. 
Glucose was determined colorimetrically according to Trinder, (1969). Aspartate aminotransferase (AST), and alanine aminotrans-ferase (ALT) activities were determined calorimetrically according to Reitman and Frankel, (1975).

\section{7- Statistical analyses:}

The obtained data were subjected to one-way ANOVA. Differences between means were tested at the 5\% probability level using Duncan's new multiple range test. All statistical analyses were done using the SPSS program V.10 (SPSS, Richmond, USA) as described by Dytham (1999).

\section{8- Economic analysis:}

The cost of feed required to produce a unit of fish biomass was estimated using economic evaluation. The estimation was based on the local retail sale market price of all the dietary ingredients at the time of the study .These prices ( in $\mathrm{LE} / \mathrm{kg}$ ) were as follows: herring fish meal, 17; soybean meal, 4.0; corn meal, 2.50; starch, 6.0; fish oil (cod liver oil), 30.0; corn oil, 12.0; linseed oil ,16.0; poultry by product oil, 2.5 ; vitamin premix, 10.0 and mineral mixture, 8.0.

\section{Results and Discussion}

\section{1- Identification of the fatty acids from the different oil samples}

The fatty acids were identified as fatty acid methyl ester by using gas chromatographic analysis where they were identified by comparison of their retention times with those of pure reference standards.

\section{1- Gas chromatographic analysis of fatty acids in linseed oil:}

It noted from fig (1) that the sample of linseed oil is major unsaturated fatty acids $(80.53 \%)$, while saturated fatty acids were at a rate of $19.47 \%$. $33.25 \%$ of the polyunsaturated fatty acids are the omega- 6 linoleic acid (C18:2 n-6) and 7.99\% are the omega-3 alpha-linolenic acid (C18:3 n-3). Over $39.29 \%$ of the monounsaturated fatty acids are oleic acid (C18:1). Of the saturated fatty acids, $8.96 \%$ are palmitic acid (C16:0), $4.40 \%$ stearic acid (C18:0), and 6.11\% arachidic acid (C20:0). 


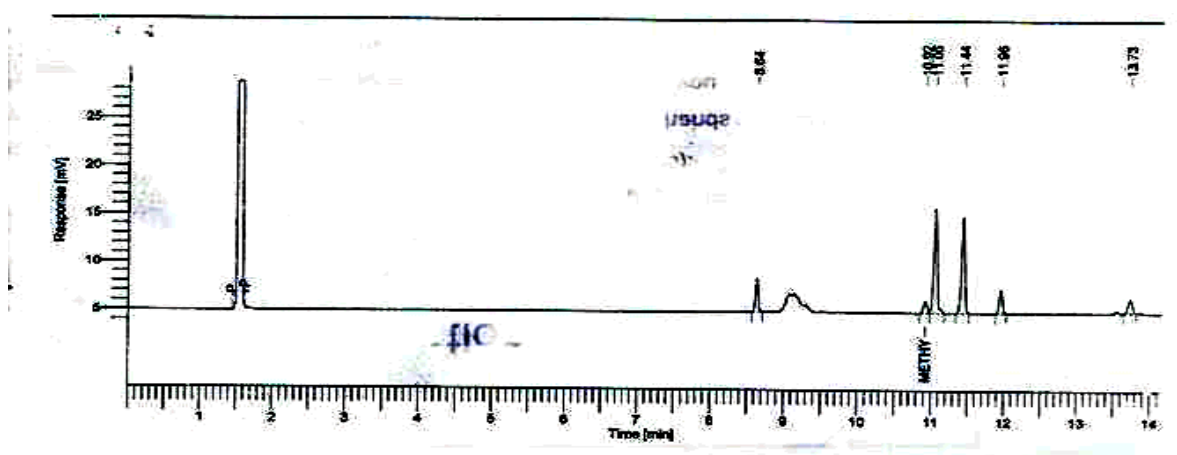

Fig (1): Typical GC chromatogram of linseed oil

\section{2- Gas chromatographic analysis of fatty acids in corn oil:}

As shown in fig (2) the fatty acids in corn oil. High levels of polyunsaturated fatty acid linoleic (C 18:2) (57.06 \%) followed by monounsaturated fatty acids oleic $(29.88 \%)$. The dominant saturated acids were palmitic (C16:0) (10.32\%) and stearic (C18:0) (2.30\%).

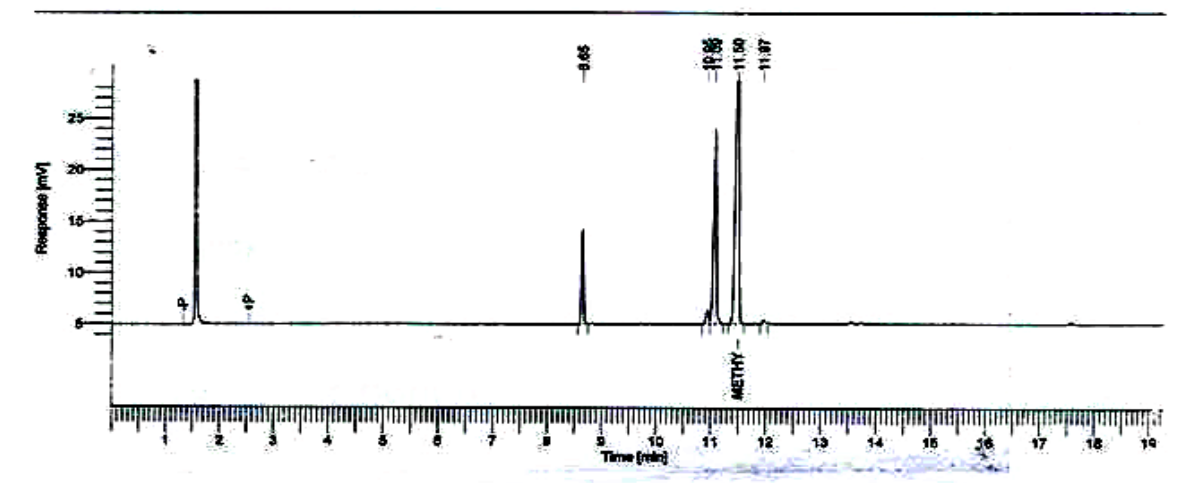

Fig (2): Typical GC chromatogram of corn oil

\section{3- Gas chromatographic analysis of fatty acids in cod liver oil.}

Fig (3) showed that the fatty acids composition of cod liver oil. The dominating monounsaturated fatty acid is oleic acid C 18: 1 (33.46\%) followed by Erucic acid C 22:1 (5.95) and Eicosenoic acid ( gadoleic acid ) $C 20: 1(5.28 \%)$. The major polyunsaturated fatty acids are the omega-6 Linoleic acid C18:2 (9.86\%) followed by the omega-3 Docosahexaenoic acid (DHA) C 22:6 (4.06\%) and octadecatetraenoic (parinaric acid) $\mathrm{C} 18: 4(3.52 \%)$. The main saturated fatty acids are palmitic C16:0 (11.37\%) followed by Docosanoic acid (behenic acid) $\mathrm{C}$ 24:0 (8.63\%) and Myristic acid C14:0 (4.09\%). Certain minor saturated 
constituents are always present, thus acids with odd numbered chains and branched chains have been found, in group's c15 and C 17.

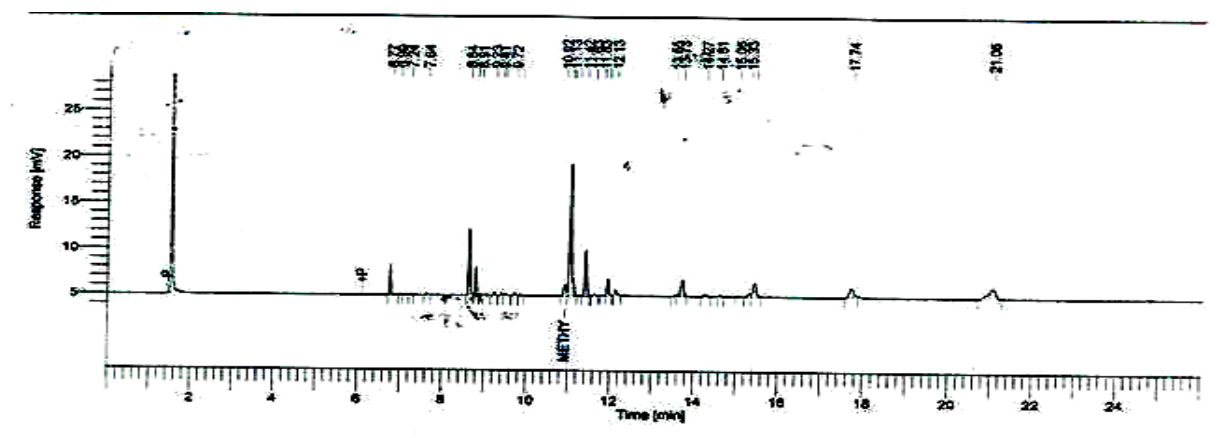

Fig (3): Typical GC chromatogram of cod liver oil

\section{4- Gas chromatographic analysis of fatty acids in poultry byproduct oil}

As shown in Fig (4) the fatty acids in poultry by product oil. Predominantly in the composition of saturated fatty acids are palmitic acid C16:0 (20.35\%), and stearic acid C 18:0 (6.89\%). The monounsaturated oleic acid C 18:1 (major fatty acid) (39.81\%). The doubly unsaturated linoleic acid C18:2 (26.12\%). The triply unsaturated $\alpha$-linolenic acid C 18:3(1.01\%).

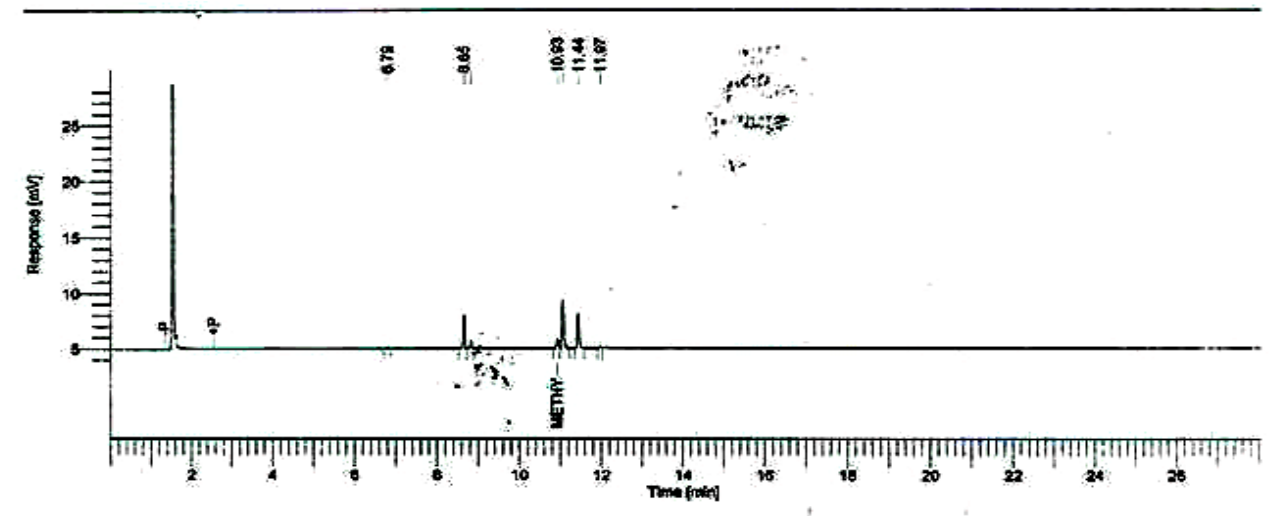

Fig(4):Typical GC chromatogram of poultry byproduct oil 


\section{2- Effect of different oil sources on growth performance and survival rate:}

Results in fig (5) indicated that Nile tilapia fingerlings fed T5 diet exhibited the highest growth performance followed by diet T3 in comparison to those fish fed the other experimental diets. However there were no significant differences among T1, T2, T3, T5 and T6 diets. Fish survival in all treatments was slightly enhanced without significant difference among the experiment groups which ranged from (97.75$100 \%$ ). The improved fish growth must be due to the presence of a mixture of essential fatty acids including linoleic, linolenic ,oleic and arachidonic acids in the tested feed additive are required to prevent fatty acid deficiency diseases (Kinsella, 1987) and essential for growth (Abdel-Latif $\boldsymbol{e t}$ al., 2004). Linseed are characterized by higher levels of linolenic (ALA, C18:3 n-3), linoleic (LA, C: 18:2 n-6) and oleic acid (18:1) than those in fish oil, and by a lack of eicosapentaenoic acid (EPA) and docosahexaenoic acid (DHA) (NRC, 1993). However it has been demonstrated that freshwater fish have an innate capacity to synthesize EPA and DHA from precursors with 18 carbon atoms (Sargent et al., 2002; Jankowska $\boldsymbol{e t}$ al., 2003). In addition to alternative lipids being cheaper, more sustainable and readily available, another beneficial characteristic is their higher resistance to lipid peroxidation (Kanner $\boldsymbol{e t}$ al., 2009). This is due to LC-PUFA deficiencies, and a higher saturated fatty acids (SFA) and monounsaturated fatty acids (MUFA) content that are less prone to oxidation, but also since some plant-based oils such as soybean oil (SBO) and linseed oil (LO) naturally contain high concentrations of vitamin E (Hamre, 2011; Ng and Wang, 2011).

These results are in agreement with these of El-tawil and Amer, (2010) found that red tilapia fed diets containing fish oil or linseed oil were significantly higher $(\mathrm{P} \leq 0.05)$ in growth performance than fish fed on other diets. Survival did not differ significantly among the fish fed different diets. Aziza et al., (2013) indicated that the diet containing 3\% cod liver oil or linseed oil produced the best growth performance. Whereas, the diet containing a blend of cod liver oil and linseed oil (1:1) at 3\% showed the poorest growth performance. Also, Yones et al., (2013) demonstrated that the highest $(\mathrm{P}<0.05)$ growth performance parameters were recorded with Nile tilapia fed diets supplemented with fish oil and a mixture of fish oil, sunflower seed oil and cotton seed oil at a ratio of 1:1:1 groups compared to other treatment groups. Moreover, El-tawil et al., (2014) showed that Nile tilapia fed diet containing fish oil FO or mixture of $(50 \%$ corn oil, $25 \%$ linseed oil and $25 \%$ soya oil) were 
significantly higher $(\mathrm{P}<0.05)$ in growth performance than fish fed on other diets. Survival rate did not differ significantly among treatments.

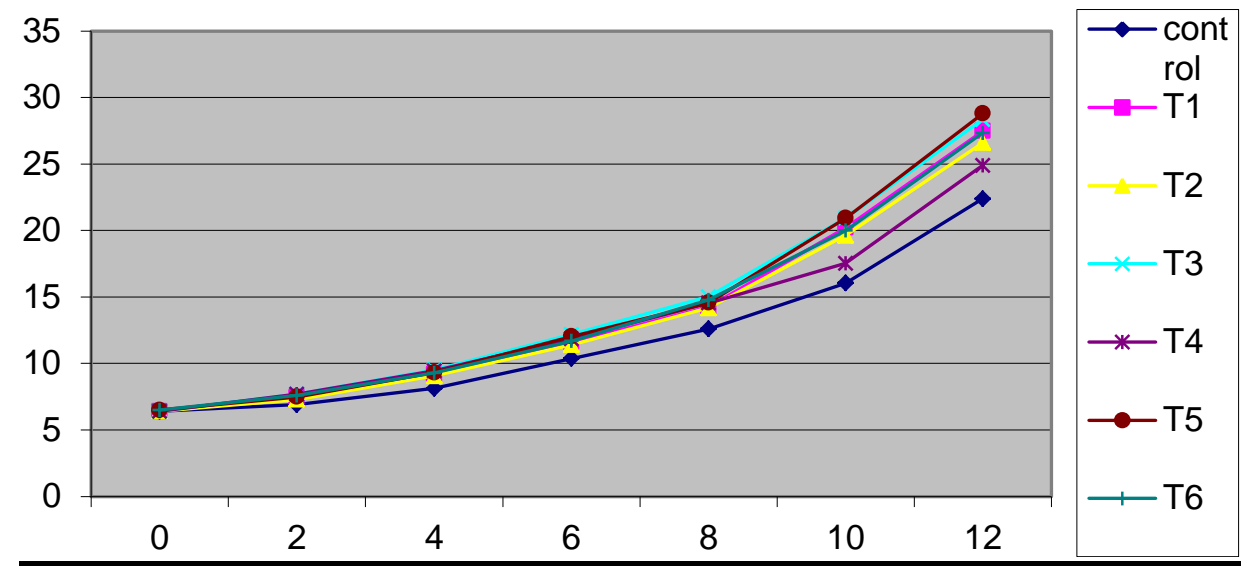

Figure (5): Changes in live body weight ( $\mathrm{g}$ ) of Nile tilapia fingerlings as affected with different oil sources for 12 weeks.

\section{3- Effect of different oil sources on feed utilization:}

Data in figure (6) show that fish fed T3 diet gave higher feed intake than other additives oil sources, followed by fish fed on T5 and T6, However there were no significant difference among T1, T3, T5 and T6 diets. Fish fed T5 diet showed the best (lowest) for feed conversion ratio in comparison to the control diet and other treatments. However there were no significant ( $p>0.05$ ) difference among fish groups fed T1, T2, T3 and T6 diets .Fish fed T5 diet show the highest feed efficiency ratio, protein efficiency ratio, apparent protein utilization and energy utilization in comparison to the control diet and other treatments, while there were no significant ( $p>0.05$ ) difference between fish group fed (T1, T3, and T5) diets. Balance between dietary protein and energy is essential in fish feed formulation. At inadequate energy levels dietary protein will be used as an energy source (Cowey, 1980), more protein is used for energy, the more ammonia is produced, and the more energy is lost as heat. But at an adequate energy level, dietary protein will be spared for growth (ElSayed, 1987). The results gathered from the study have demonstrated that the vegetable oil sources used are of good nutrient composition. This observation could imply that there was no palatability problem and that their utilizations were adequate. Results of this study agree with El-tawil and Amer , (2010) indicated that values of feed conversion ratio FCR were improved significantly at red tilapia (Oreochromis sp.) maintained at fish oil (FO) and linseed oil (LO) diets compared to other treatments, 
and the highest values of PER, PPV\% and ER\% were obtained with fish fed FO and LO diets. Moreover, El-tawil et al., (2014) indicated that feed conversion ratio FCR and feed utilization parameters of Nile tilapia (Oreochromis niloticus) were improved significantly at fish maintained at fish oil(FO) and ML diets; mixture of (50\% corn oil CO, $25 \%$ linseed oil LO and $25 \%$ soya oil SO) compared to other treatments.

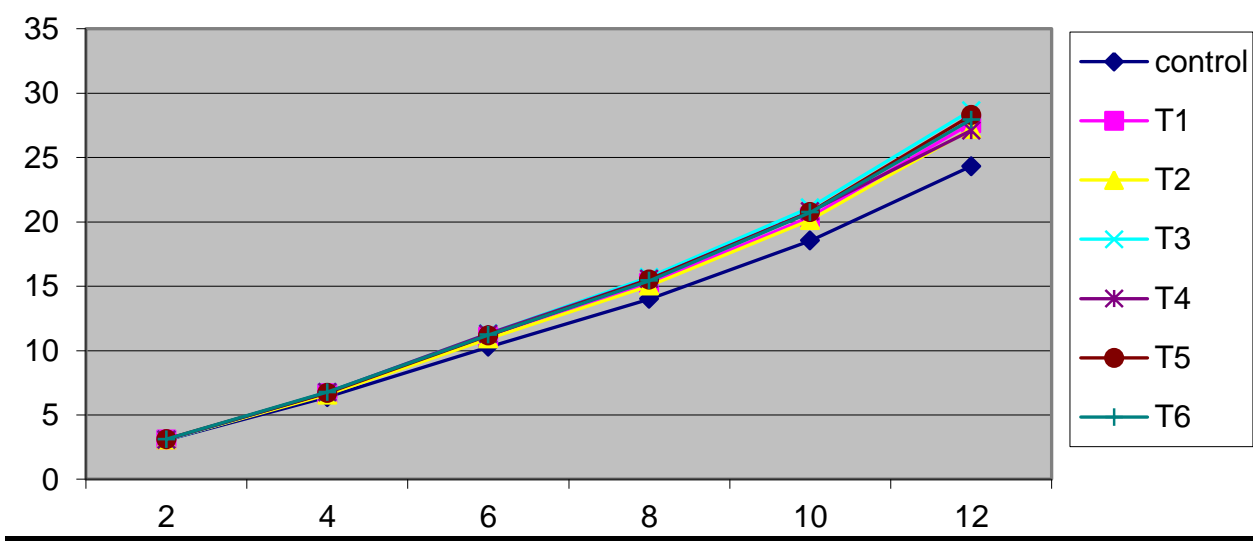

Figure (6): Changes in feed intake ( $\mathrm{g}$ feed/fish) of Nile tilapia fingerlings as affected with different oil sources for 12 week.

\section{4- Effect of different oil sources on whole fish body composition:}

Results in figure (7) indicated that moisture and ash contents were not significantly affected $(\mathrm{p}<0.05)$ with fish fed diets containing various oil in comparison to the initial fish. On the other hand, there were no significant differences with fish protein and lipid contents $(P>0.05)$ in all diets supplemented with different oil sources. The highest protein content was recorded at fish fed T5 diet. Fish fed T5 and T2 gave higher lipid content as compared to other oil sources. The composition of the feed is the only factor, which could have influenced the difference chemical composition of fish that data on the body composition of fish allows assessing the efficiency of transfer of nutrients from feed to fish and also helps predict the overall nutritional status .The n-3/n- 6 fatty acid ratio can also alter lipid and protein contents in fish muscle (Robaina et al., 1998).

Our obtained results are in accordance with El-tawil and Amer, (2010) showed that there were no significant differences for Oreochromis sp body moisture or protein contents in all various dietary oil sources. Lipid content concentrations were affected by dietary treatments. Fish fed diets contained olive oil and sunflower oil was significantly lower in body lipid contents than those fed on other diets $(\mathrm{P} \leq 0.05)$. Furthermore 
El-tawil et al., (2014) reported that there were no significant differences in fish body moisture or protein contents of Nile tilapia at all treatments; fish oil; linseed oil, corn oil,; soya oil,; mixture of (50\% linseed oil, $25 \%$ corn oil and $25 \%$ soya oil ), ML; mixture of (50\% corn oil , $25 \%$ linseed oil and $25 \%$ soya oil ), and mixture of (50\% soya oil , $25 \%$ linseed oil and $25 \%$ corn oil ). Fish body lipid content differs significantly.

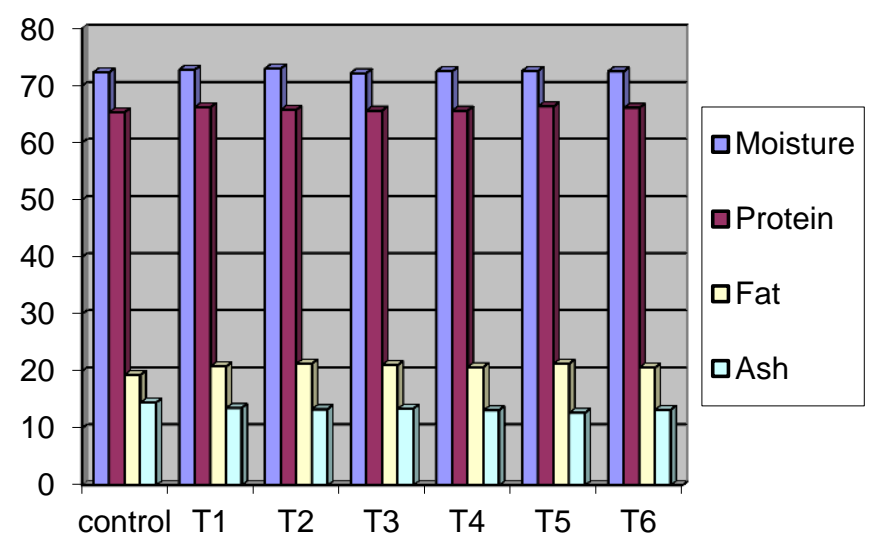

Figure (7): Changes in proximate chemical analysis (\%) on DM basis in whole body of Nile tilapia as affected with different oil sources for 12 weeks.

\section{5- Effect of different oil sources on physiological parameters:}

Blood chemistry parameters can be used to assess the health status and as stress indicators in fish (Kumar et al., 2010 and De Pedro et al., 2005). Also, haematological parameters can provide information on nutrient status, digestive function, and routine metabolic level of fishes (Shah and Altindag, 2005). Red and white blood cell counts are used as indicators of hematopoiesis. White blood cells play an important role in immune responses, particularly in inflammatory responses (Secombes, C.J., 1996). In this study results in figure (8) indicate that hematological parameters of Hemoglobin, Red blood cells and Haematocrit were higher in Nile tilapia fed T5 (50\%linseed oil $+50 \%$ poultry by product oil) diet. The lowest $\mathrm{Hb}$ was recorded with $\mathrm{T} 6$, while the lowest R BCs were found when fish fed control diet. There were no significant differences $(p>0.05)$ in $\mathrm{Ht}$ of Nile tilapia fed diets containing various oil sources. The lack of significant differences in hematologic parameters $\mathrm{Ht}$ among different oil sources explains that multiple sources of fat have been efficient in providing the fish fingerling with the demanded essential oils so that no signs of deficiency of essential fatty acids, like increase in hemoglobin and hematocrit were observed in fish fed with 
vegetable oils. Similar results were obtained with Karimi et al., (2014) reported that hematologic factors including hemoglobin and hematocrit showed no significant differences between diets containing different oils, including treatment with $100 \%$ fish oil, linseed oil and 1:1 ratio of fish and linseed oil.

The concentration of total plasma protein is used as a basic index for the health status of brood fish Rehulka et al., (1996). The most portion of serum protein synthesis is in the liver and it can be used as an indicator of liver dysfunction. The reduction of total protein concentration is the obvious feature of many diseases and may occur due to liver disease, the absorption reduction or the loss of protein (Bernet $\boldsymbol{e t}$ al., 2001). In our study, total protein serum was increased significantly in the group of fish consumed T5 diet in comparison to other treatments, while the lowest total protein were recorded with control diet as in figure (9). These results agree with these of Sotolu, (2010) who reported that blood protein was significant differences among the treatments of which value was highest in diet containing soybean oil and least in diet containing benni seed oil.

Albumin is of considerable diagnostic value in laboratory animals as it relates to general nutritional status, the integrity of the vascular system and liver function. Moreover, albumin and globulin concentrations are commonly used for evaluating the effect of nutrients on the fish immunity Nguyen, (1999). Our result showed that there was no significant $(\mathrm{P}<0.05)$ difference in serum albumin among diets containing various oil sources; however the highest value of Serum albumin was obtained at T3 diet. These results contrast the finding of Karimi et al., (2014) who showed that there were significant differences in the factors of total Protein, albumin among diets containing different oils, including treatment with $100 \%$ fish oil, linseed oil and 1:1 ratio of fish and linseed oil.

The determination of glucose concentration in blood serum is widely used as an indicator of stress in fish (Bonga, 1997 and Martin and Black, 1998). On the other hand, changes in levels of glucose in serum can be due to malnutrition or an injured kindney (Jacobson and Keller, 2001). In the present study, serum glucose was significantly increased at fish group consumed T5 diet. The increase of serum glucose levels as an indicator of fish metabolic rate. Similarly El-kasheif et al., (2011) show that protein, glucose and cholesterol for fish fed diet containing the 
highest supplemented lipid (9\%) level were significantly different $(\mathrm{p}<$ $0.05)$.

Alanine aminotransferase (ALT) and aspartate aminotransferase (AST) belonging to the non-plasma specific enzymes which are localized within tissue cells of liver, heart, gills, kidneys, muscle and other organs Peter et al., (2007). In the present study, dietary supplementation of T5 cause a significant decrease in serum ALT levels, while the highest value recorded at the control diet. Also data indicated that there was no significant differences in serum AST among various fish group, however AST level lower in fish fed T5 diet. These results agree with Karimi $\boldsymbol{e t}$ al., (2014) reported that that there were no significant differences in AST and ALT among diets containing different oils, including treatment with $100 \%$ fish oil, linseed oil and 1:1 ratio of fish and linseed oil.

Urea is present in all fish, the liver being the primary organ of production and the gills appearing to be the main organ of excretion Walsh $\boldsymbol{e t}$ al., (2003) and in the low protein diet group the serum urea levels were significantly lower than in the other groups, indicating depressed urea genesis Divino et al., (1999). In our study the highest value of urea was obtained at diet containing T2 diet and T6 diet. While urea value decreased significantly in $\mathrm{T} 5$ diet containing and $\mathrm{T} 3$ diet.

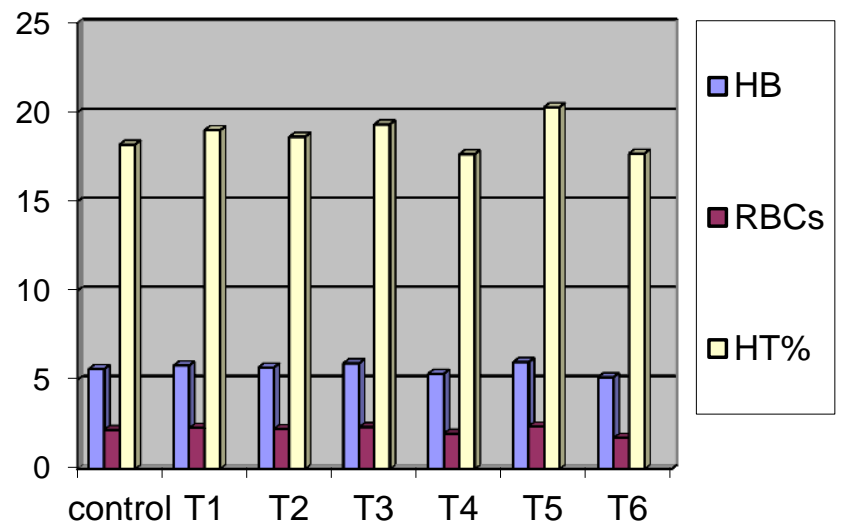

Figure (8): Changes in hemoglobin ( $\mathrm{Hb})$, red blood cell (RBCs) and haematocrite (Ht) in blood of Nile tilapia fingerlings as affected with different oil sources as feed additives for 12 Weeks. 


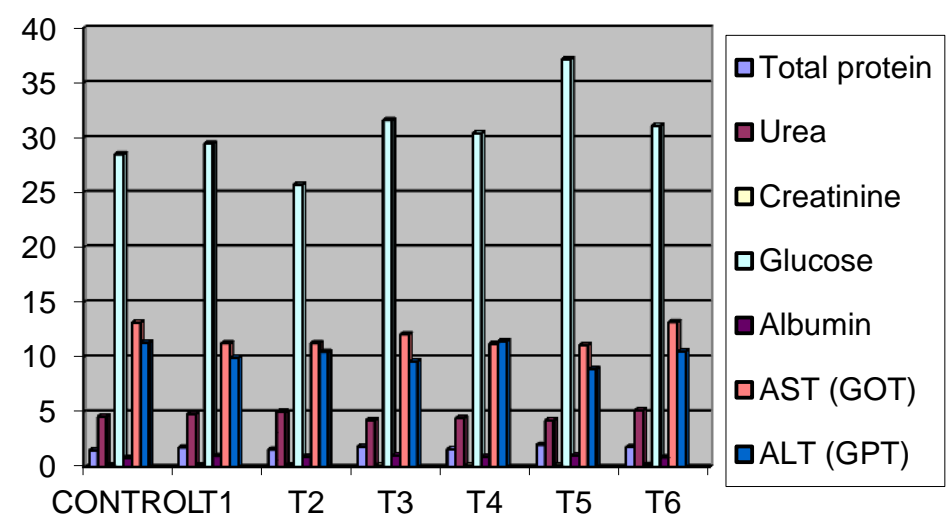

Figure (9): Bio-chemical blood changes of Nile tilapia fingerlings as affected with different oil sources for 12 weeks.

\section{6-Economic analysis of Nile tilapia as affected with different oil sources:}

Economic analysis show that feed cost and feed cost $/ \mathrm{kg}$ gain were high at the control diet than oil supplemented diets (Table 2). Feed cost to produce one kilogram fish gain was reduced in T5, T2, and T6 than those fed the control diet. The reduction in feed cost compared with the control diet to produce one $\mathrm{kg}$ fish gain was highest in $\mathrm{T} 2$ diet followed by $\mathrm{T} 5$ then T6 diet and T3 diet. These results are nearly similar with those reported by Piedecausa et al. (2007) who noted that, the consumption of vegetable oils reduced feed costs of sharpsnout seabream. El-Tawil and Amer (2010) found the same results in red tilapia where replacement fish oil by linseed oil reduced oil cost in fish feed more than $87 \%$ without any effect on growth. Also, El-tawil et al., (2014) showed that the efficiency of replacement fish oil by linseed oil in Nile tilapia diet is more economic and sharply reduced the fish feed cost.

Table (2): Economic evaluation of Nile tilapia fingerlings as affected with different oil sources for 12 weeks.

\begin{tabular}{|l|c|c|c|c|c|c|c|}
\hline \multirow{2}{*}{\multicolumn{1}{|c|}{ Items }} & Control & \multicolumn{7}{c|}{ Types of oils } \\
\cline { 3 - 8 } & $\mathbf{0 . 0}$ & T1 & T2 & T3 & T4 & T5 & T6 \\
\hline Cost/ kg feed (L) & 4.79 & 6.11 & 4.73 & 5.40 & 5.11 & 5.07 & 4.97 \\
\hline FCR (kg feed/ kg gain) & 1.69 & 1.31 & 1.34 & 1.3 & 1.47 & 1.27 & 1.34 \\
\hline Feed cost/ kg gain (L) & 8.09 & 8.0 & 6.34 & 7.02 & 7.51 & 6.44 & 6.66 \\
\hline $\begin{array}{l}\text { Feed cost in kg gain (\%) as } \\
\text { percentage of the control }\end{array}$ & 100 & 98.89 & 78.37 & 86.77 & 92.83 & 79.60 & 82.32 \\
\hline $\begin{array}{l}\text { Reduction in feed costs to } \\
\text { produce kg gain }\end{array}$ & 100 & 1.11 & 21.63 & 13.22 & 7.17 & 20.39 & 17.68 \\
\hline
\end{tabular}




\section{Conclusion}

In general results of the present study may lead us to conclude that incorporation of mixture of linseed oil and poultry by product oil $(50 \%$ linseed oil+ $50 \%$ poultry by product oil) in the diet of Nile tilapia (Oreochromis niloticus) showed the best growth performance parameters and physiological parameters followed by linseed oil diet

\section{Recommendation}

Mixture of linseed oil and poultry by product oil (50\% linseed oil+ $50 \%$ poultry by product oil) in the diet of Nile tilapia (Oreochromis niloticus) showed the best growth performance parameters, suggesting the addition of this oils to Nile tilapia feed since it's more efficiency economic, available and sharply reduced the feed cost of Nile tilapia.

\section{References}

Abdel-Latif, S.A.A.; El-Yamany, A.T. and Edaly, E.A.F. (2004). Evaluation of using different levels and sources of medicinal herbs in growing Japanese quail diets. Egyptian Journal of Nutrition and Feeds, 7 (1): 69-81.

AOAC, (1990). Association of official analytical chemists. The Official Methods of Analyses Association of Official Analytical Chemists International. $5^{\text {th }}$ edition, Arlington, VA, USA.

Aziza, A.E.; Awadin, W.F. and Orma, A.M. (2013). Effect of dietary substitution of cod liver oil by vegetable oils on growth performance, body composition, lipid peroxidation, liver and muscle histopathological state in Nile tilapia (Oreochromis niloticus). Journal of Fisheries and Aquaculture, 4(2): 87-94.

Bell, J.G.; McEvoy, J.; Tocher, D.R.; McGhee, F.; Campbell, P.J. and Sargent, J.R. (2001). Replacement of fish oil with rapeseed oil in diets of Atlantic salmon (Salmo salar) affects tissue lipid composition and hepatocyte fatty acid metabolism. Journal of nutrition, 131(5): 1535-1543.

Bell, J.G. and Sargent, J.R. (2003) - Arachidonic acid in aquaculture feeds: current status and future opportunities - Aquaculture , 218: 491-499.

Bernet, D.; Schmidt, H.; Wahli, T. and Burkhardt-Holm, P. (2001). Effluent from a sewage treatment works causes changes in serum 
chemistry of brown trout ( Salmo trutta). Ecotoxicology and Environmental Safety, 48(2): 140-147.

Bonga, W.S.E. (1997). The stress response in fish. Physiological Reviews , 77(3): 591-625.

Caballero, M.J.; Obach, A.; Rosenlund, G.; Montero, D.; Gisvold, M. and Izquierdo, M.S. (2002). Impact of different dietary lipid sources on growth, lipid digestibility, tissue fatty acid composition and histology of rainbow trout, Oncorhynchus mykiss. Aquaculture, 214: 253-271.

De Pedro, N.; Guijaroo, A.E.; Lopez-Patino, M.A.; MartinezAlvarez, R. and Delgado M.J. (2005). Daily and seasonal variations in haematological and blood biochemical parameters in tench (Tinca tinca). Aquaculture Research, 36: 1185-1196.

Divino, J.C.; Filho, S.; Hazel, J.; Anders tam, B.; Bergst röm, J.; Lewitt, M. and and Hall, K. (1999). Effect of protein intake on plasma and erythrocyte free amino acids and serum IGF-I and IGFBP1 levels in rats. American Journal Physiology Endocrinol Metabolism, 277: 693-701.

Dytham, C. (1999). Choosing and Using Statistics: A Biologist'sGuide. Blackwell Science Ltd., London, UK. pp 147.

El -Kasheif, M.A.; Saad, A.S. and Ibrahim, S.A. (2011) . Effects of varying levels of fishoil on growth performance, body composition and haematological charchteristics of Nile tilapia Oreochromis niloticus (L). Egypt Journal of Aquculture Biology and Fish, 15(1): $125-141$.

El- Sayed, A.M. (1987). Protein and energy requirements of Tilapia Zillii PH.D.Diss., Michigan state university. East lansing MI, USA, $147 \mathrm{PP}$.

El-tawil, N.E.; Ahmad, M.H.; Amer, T.N. and Seden, M. (2014). Effect of replacing dietary fish oil with different plant oils on growth performance of Nile Tilapia Oreochromis niloticus. The Journal of Applied Science Research, 1(3): 2383-2215

El-tawil, N.E. and Amer, T.N. (2010). Effect of different dietary oil sources on fish performance, feed utilization and body composition of red tilapia (oreochromis sp.) fry. The third scientific conference, Al Azhar University, Cairo: 17-18. 
Goering, H.K. and Van Soest, P.G. (1970). Forage fiber analysis (apparatus, reagent, rocedures, and some aplicatons). Washington, DC: U.S. Dept. of Agriclture.

Hamre, K. (2011). Metabolism, interactions, requirements and functions of vitamin $\mathrm{E}$ in fish. Aquaculture Nutrition, 17: 98-115.

Henry, R.J. (1964). Colorimetric determination of total protein. In:n Clinical Chemistry. Harper and Row Publication, New York, USA.

Jacobson-Kram, D. and Keller, K.A. (2001). Toxicology testing handbook. Marcel Dekker, New York, 282- 283.

Jankowska, B.; Zakęś, Z.; Żmijewski, T. and Szczepkowski, M. (2003). A comparison of selected quality features of the tissue and slaughter yield of wild and cultivated pikeperch, Sander lucioperca (L.). The journal European Food Research and Technology, 217: 401405.

Joseph, A.; Kinght, M.; Anderson, S.; James, M. and Rewie, H. (1972). Chemical basis of the sulfophospho vanillin reaction for estimating total serum lipid. Clincial Chemistry, 18: 198-201.

Kanner, J.; German, J.B.; Kinsella, J.E. and Hultin, H.O. (2009). Initiation of lipid peroxidation in biological systems. Critical Reviews in Food Science and Nutrition, 25: 317-364.

Karimi, M.R; Ebrahimi, E.; Soofiani, N.M. and Masiha, A. (2014). Replacement of Dietary Fish Oil with Flaxseed Oil and its Effects on Hematological and Biochemical Parameters of Rainbow Trout Fingerlings (Oncorhynchus mykiss). World Journal of Fish and Marine Sciences, 6 (3): 209-213.

Kinsella, J.E. (1987). Sea foods and human health and diseases. Marcel Dekker Inc. New York and Basel.

Kumar, B.; Senthikumar, K.;Priya, M.; Mukhopadhyaya, D.P. and Saha, R. (2010). Distribution of trace elements in water, sediment and fish from sewage fed fish ponds in eastern Kolkata, India. Toxicology and Enviromental Chemistry, 92 (2):243-260.

Martin, J.L.K. and Black, M.C. (1998). Biomarker assessment of the effects of coal-strip mine contamination on channel catfish. Ecotoxicology and Environmental Safety, $41: 307-320$.

Martins, D.A.; Valente, L.M.P. and Lall, S.P. (2009). Apparent digestibility of lipid and fatty acids in fish oil, poultry fat and 
vegetable oil diets by Atlantic halibut, Hippoglossus hippoglossus L. Aquaculture, 294:132-137.

Menoyo, D.; Lopez-Bote, C.J.; Diez, A.; Obach, A. and Bautista, J.M. (2007). Impact of $n-3$ fatty acid chain length and $n 3 / n 6$ ratio in Atlantic salmon (Salmo salar) diets. Aquaculture, 267: 248-259.

National Research Council, N.R.C. (1993). Nutrient requirements of fish. Committee on Animal Nutrition. Board on Agriculture. National Research Council. National Academy Press. Washington DC, USA.

Natt, M.P. and Herrick, A.C. (1952). A new blood diluent for counting the erythrocytes and leukocytes of chicken. Poultry Science 31:735738 .

Ng, W.K. and Wang, Y. (2011). Inclusion of crude palm oil in the broodstock diets of female Nile tilapia, Oreochromis niloticus, resulted in enhanced reproductive performance compared to brood fish fed diets with added fish oil or linseed oil. Aquaculture, 314: 122-131.

Nguyen, H.T. (1999). Transport proteins, In: Loeb, W.F.; Quimby, F.W. (Eds), The clinical chemistry of Laboratory Animals, Second Edition. Taylor and Francis, Philadelphia, PA, USA, 309-335.

Patton, C.J. and Crouch, S.R. (1977). Determination of urea. Analytical Chemistry, 49: 464-469.

Piedecausa, M.A.; Mazón, M.J.; García García, B. and Hernandez, M.D. (2007). Effects of total replacement of fish oil by vegetable oils in the diets of sharpsnout seabream (Diplodus puntazzo). Aquaculture, 263: 211-219

Reitman, S. and Frankel, S. (1975). Colorimetric determination of glutamic oxaloacetic and glutamic pyruvic transaminase. Journal Clincal Pathology, 28-56.

Rehulka, J. (1996). Blood parameters in common carp with spontaneous spring Viremia (SVC). Aquaculture International, 4: 175-82.

Robaina, L.; Izquierdo, M.S.; Moyano, F.J.; Socorro, J.; Vergara, J.M.; and Montero, D. (1998). Increase of the dietary n-3/n-6 fatty acid ratio and addition of phosphorous improves liver histological alterations induced by feeding diets containing soybean meal to gilthead seabream, Sparus aurata. Aquaculture, 161: 281-293. 
Sargent, J.R.; Tocher D.R. and Bell J.G. (2002). The lipids - In: Fish nutrition (Eds) R.W. Hardy, J.E. Halver, Academic Press, San Diego, CA, USA: 181-257

Schalm, O.W. (1975). Veterinary Haematology 3rd Ed, Bailliere, Tindall and Cassel Ltd., London.

Secombes, C.J.; Hardie, L.J. and Daniels, G. (1996). Cytokines in fish: An update. Fish and Shell fish Immunology, 6: 291-304

Shah, S.L. and Altindag, A. (2005). Alternation of immunological parameters of tench ( Tinca tinca) after acute and chronical exposure to lethal and sublethal treatments with mercury, cadmium and lead. Turkish Journal Veterinary and Animal Sciences, 29:11631168 .

Sotolu, A.O. (2010). Feed utilization and biochemical characteristics of Clarias gariepinus (Burchell, 1822) fingerlings fed diets containing fish oil and vegetable oils as total replacements. World Journal of Fish and Marine Sciences, 2(2): 93-98.

Trinder, P. (1969). Serum glucose determination. Ann. Biochem., 6:24. Cited from Boehringer Mannheim Gmth Diagnostica Kit.

Tsimidou, M. and Boskou, D. (1995). Adulteration, in: A. Townshend (Ed.), Encyclopedia of Analytical Science, Vol. 1, Academic Press, London, p. 42.

Walsh, P.J.; Mayer, G.D.; Medina, M.; Bernstein, M.L.; Barimo, J.F. and Mommsen, T.P. (2003). A second glutamine symthetase gene with expression in the gills of Gulf toadfish (Opsanus beta). Journal of Experimental Biology, 206: 1523-1533.

Yones, A.M.; El-Saidy, D.M.S.D. and Abdel-Hakim, N.F. (2013). Effects of fish oil substitution with vegetable oils in diets of juvenile Nile tilapia, Oreochromis niloticus (L.) on growth performance, nutrients utilization and muscle fatty acids contents. Merit Research Journal of Food Science and Technology, 1(1): 009-018. 
تأثير العلائق التى تحتوى على مصادر مختلفه من الزيوت على اداء النمو ونركيب الجسم

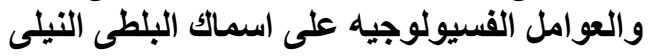

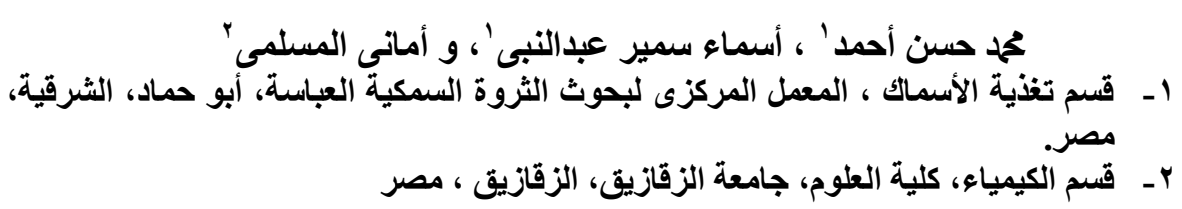

\section{الملخص العربي}

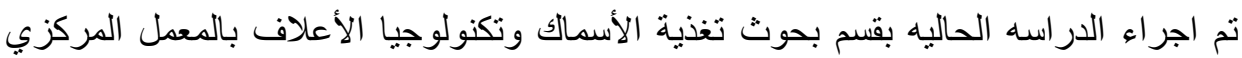

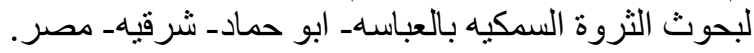

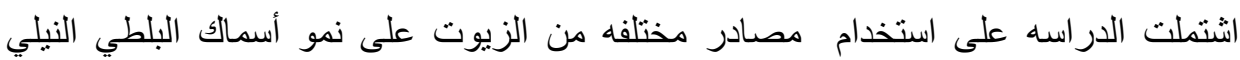

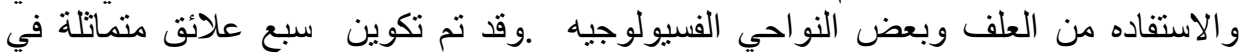

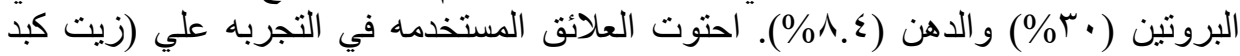

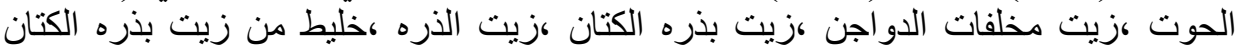

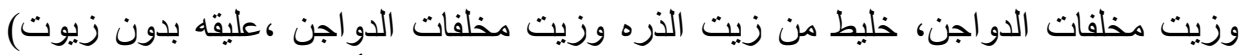

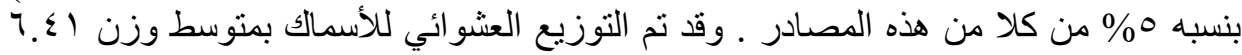

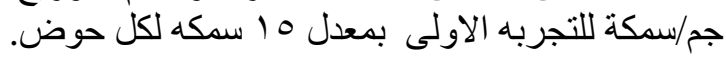

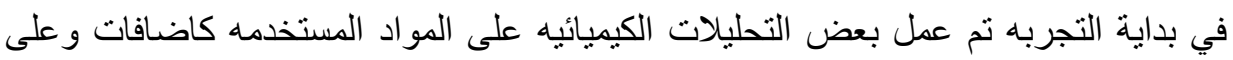

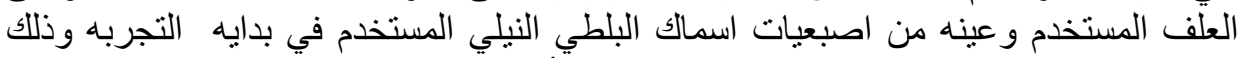

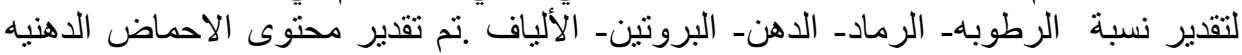

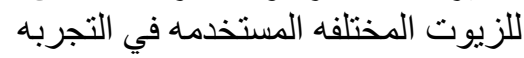

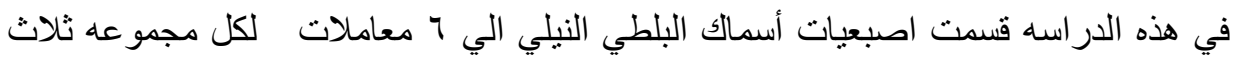

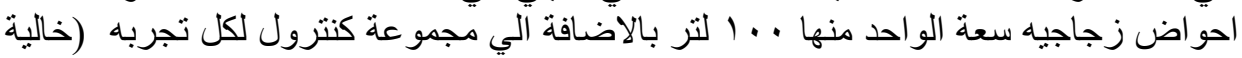

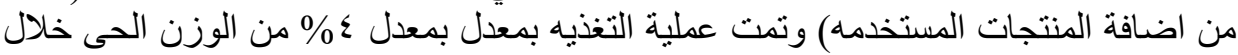

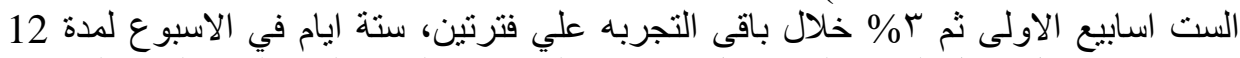

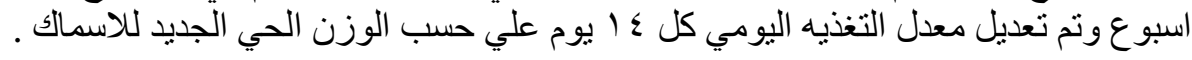

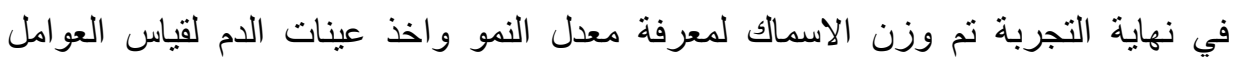

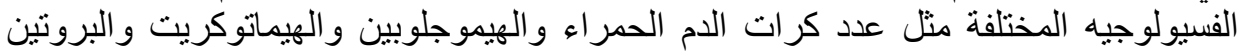

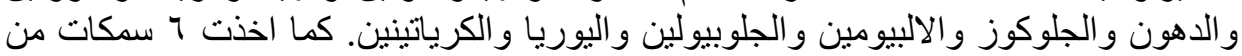

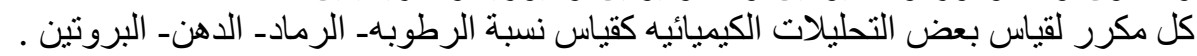
أظهرت التجربه النتائج الاتيه:ا ـ حدوث تحسن في نمو الاسماك بوجود مصادر مختلفه من الزيوت مقارنه بالكنترول (بدون زيوت)

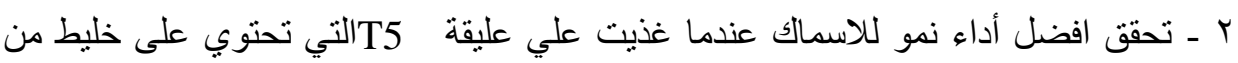

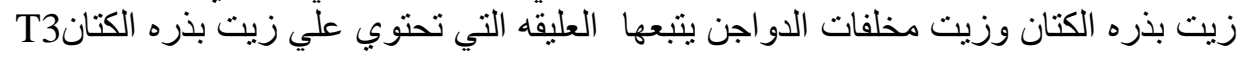




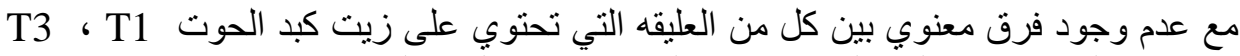

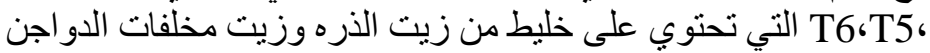

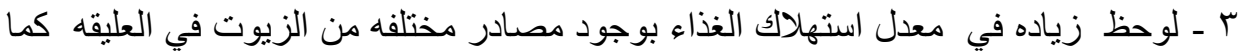

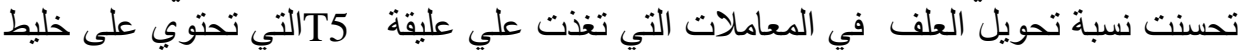

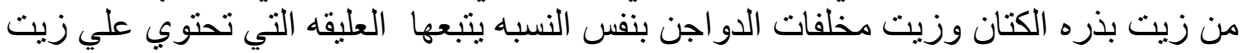

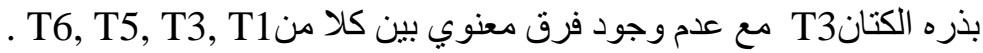

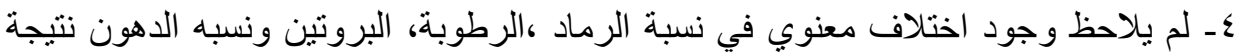

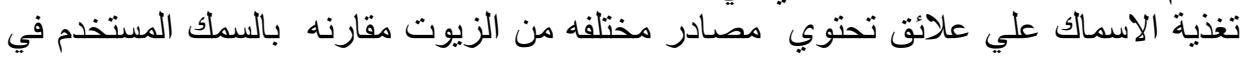

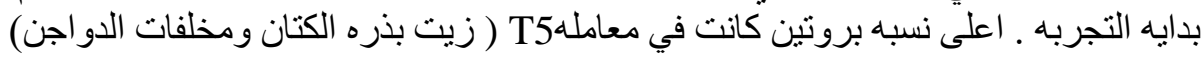

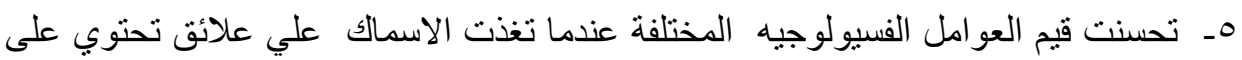

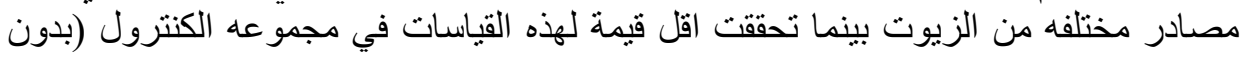

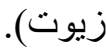

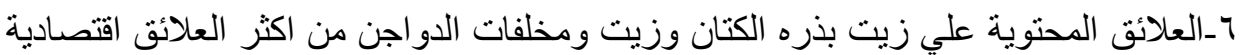

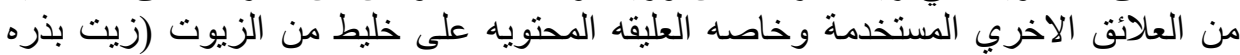

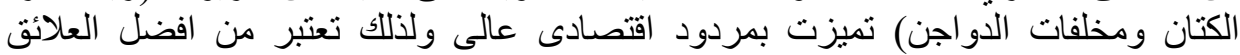
المستخدمه وذلك لاحتو ائها مصدر نباتى بالاضافه للمصدر الحيو انى. 